\title{
19
}

\section{Contribution of the information technology/information systems to human resources management in the university}

\author{
J. Rodríguez, J. Osorio and R. Berriel
}

Departamento de Economía y Dirección de Empresas. Universidad de Las Palmas G.C. Saulo Torón, 4, 35017 Las Palmas de Gran Canaria, Spain

\begin{abstract}
This paper deals with the human resources department in the university, and it is focused on two different issues, both of them related to each other. First, we analyse theoretically the human resources in the organizations and how to develop the function of human resources in the Spanish public university environment, specifically in the University of Las Palmas de Gran Canaria (ULPGC). Second, we conclude with a Human Resources Department design in which we have in mind the main functions and activities to develop inside the aforementioned department, analysing the information needed and proposing an IS design to support the activities carried out in this type of department.
\end{abstract}

Keyword Codes: H.1.1; J.1; J.4

Keywords: Systems and Information Theory; Administrative data processing; Social and Behavioral Sciences

\section{INTRODUCTION}

This paper will describe the application of Information Systems and Information Technology (IS/IT) to management in educational institutions, and in particular in universities. It is based on an overall analysis which was undertaken with a view to discovering how IS/IT could contribute to improved management performance.

The main supporting framework was Porter's Value Chain [1], though it is recognized that this analytical tool has been subject to criticism because of the difficulty of adapting it to nonprofit service industries [2]. Based on some one hundred in-depth interviews with senior university management (Rector Management Committee, Directors of various Centres, Heads of Departments, and Non-academic Support Department Heads), a value chain model was developed for the University of Las Palmas de Gran Canaria (ULPGC), which may in principle be applicable to any western type university.

This adaptation of Porter's model was not straightforward and considerable debate arose, e.g. over the role played by the students (raw material that undergoes transformations; clients requiring training; a productive element, taking part in their own education); and about what might be considered as the "profit" margin, i.e. social benefits, cost savings, etc. Nevertheless it can be said that with the aid of this model some priority areas can be identified and defined for the development of IS/IT in the university. 
In order to test the findings resulting from the above approach, the Critical Success Factors (CSF) model was later applied independently [3]. Similar results were obtained. Five high priority development areas, or projects, emerged immediately and these were initiated simultaneously. The remainder, some six or seven further areas in which IS/IT might help management improvement, were held over for later research as, given their relatively minor importance in the university's value chain, their implementation was less urgent. In this sense it must be pointed out that the value chain has shown itself to be an enormously powerful tool for identifying areas of interest and for establishing research priorities.

From the five IS/IT development projects initiated in the areas of library services, student academic counselling services, department management, property management and human resources management, the last one was chosen for this paper as it constitutes a good example of how to identify opportunities for organizational improvements through IS/IT and how to implement them.

\section{ANALYSIS}

Human resources management is an area of particular interest because its proper administration has a direct impact on the overall results of the university, which is a humancapital intensive institution. The choice of an appropriate procedure becomes especially crucial when developing an IS to support that function. For this reason, the methodology followed in the development of this project is based on the Information System Life Cycle which, as has been shown elsewhere [4-7], is the most widely accepted in its different variants. Alongside this we have applied principles of structured analysis and design.

Thus, the first step involved a theoretical revision of those activities which, in the view of other specialists in the field [8-10], should be undertaken by a human resources department, in order to contrast them later with those which are carried out by the ULPGC and to test their level of implementation. The revision of the present system was not only done to highlight those activities which were either inadequately carried out or not at all, but also to consider the different ways information technology would improve each activity, especially by means of the latest advances in data-base technologies, communications, and multimedia.

The result of this research is summarized in Table 1, which brings together fourteen activities concerning human resources management in an organization. It shows the level of IS/IT use reached at the ULPGC and the development proposal which ultimately emerged. As can be seen, the already computerized activities are, in general, those most closely related to the administrative processes which are most strongly regulated in state universities, i.e. recruitment, selection, salary administration, and the social benefit plan. It is assumed that this is a general pattern in other universities.

On the other hand, for five activities -socialization, organizational development, motivation, health and safety, and human resources auditing- IS support provides no significant advantages compared to traditional ways of working. This may be the result either of the highly unstructured nature of the tasks, which makes their systematization difficult if not impossible, or of the ineffectiveness of systematized information in these cases.

Finally, four activities were identified -analysis and description of jobs, career development, performance evaluation, and training and development- for which substantial performance advantages could be obtained with the support of adequate information systems. 
At this stage, an analysis of information needs for each activity was carried out based on a detailed study undertaken in conjunction with senior management of the Human Resources Department. From this study a list of system requirements emerged, serving as a cornerstone on which the design of the system was subsequently based. This involved the exhaustive analysis and description of the tasks to be undertaken in each activity in order to identify information needs related to content, availability, reliability, and styles of presentation. To this end a series of techniques and research tools were employed, such as interviews, flow charts, organization tables, job descriptions, direct observation, and the examination of the work of similar departments in other universities.

Table 1.

IS/IT support to activities concerning human resource management.

\begin{tabular}{llll}
\hline \hline $\begin{array}{l}\text { HUMAN } \\
\text { RESOURCES }\end{array}$ & ACTIVITY & $\begin{array}{l}\text { CURRENT } \\
\text { STATE }\end{array}$ & PROPOSAL \\
\hline Provision & $\begin{array}{l}\text { Recruiment } \\
\text { Selection } \\
\text { Socialization }\end{array}$ & $\begin{array}{l}\text { AIS } \\
\text { AIS } \\
\text { No AIS }\end{array}$ & \\
\hline Application & Analysis and job description & NO AIS & DIS \\
& Planning and forecasting & AIS & DIS \\
& Career development & NO AIS & DIS \\
\hline Development & Performance evaluation & NO AIS & DIS \\
& Training and development & NO AIS & \\
\hline Maintenance & Organizational development & NO AIS & \\
& Motivation & NO AIS & AIS \\
& Salary administration & AIS & \\
\hline Audit & Social benefits plan & NO AIS & \\
\hline \hline
\end{tabular}

$\begin{array}{ll}\text { AIS } & \text { Activity undertaken with IS/IT support } \\ \text { NO AIS } & \text { Activity undertaken without IS/IT support } \\ \text { DIS } & \text { Develop IS support }\end{array}$

\section{TECHNICAL SOLUTION}

At the macro-design level two alternative technical solutions can be proposed:

a) To develop autonomous information systems for the abovementioned activities, i.e. independent of other systems already implemented within the university.

b) To integrate the new systems with those already existing, using the data-base technology available in the university besides its hardware, mainframe and communication system infrastructure. 
Although the choice of the second option, with greater integration and better use of existing resources, might initially seem obvious, the difficulty was that the university's systems run on a proprietary-brand operating system, while our project presented the opportunity to migrate to an open system. Once the pros and cons were evaluated, option $b$ was finally chosen, mainly because most of the necessary data for the new systems would be shared with the one already running. This choice determined the grounding technology to be employed: that already in use within the university, namely, an IBM 9121 mainframe with $15 \mathrm{~Gb}$ on HD and $64 \mathrm{Mb}$ of RAM; IBM 3745 communication unit, VM/ESA operating system and IBM's SQL/DS database management software.

It remained to design the structure of the data files on which the new system was to be based, including the relation between these and those already existing, as well as a computer application which would allow us to capitalize on the information as required in the analysis undertaken. Consequently, a four-module computer application was designed for structured information management which included querying, record creation, record removal, and record editing. The system's safety mechanisms were defined, including access authorization.

In Table 2, the main features of the eighteen resulting files are presented. Altogether they contain over 240 data fields.

Table 2.

Resulting files of the design stage.

\begin{tabular}{|c|c|c|}
\hline ACTIVITY & $\begin{array}{l}\text { TYPE OF } \\
\text { PERSONNEL }\end{array}$ & FILES \\
\hline \multirow[t]{2}{*}{$\begin{array}{l}\text { ANALYSIS AND JOB } \\
\text { DESCRIPTION }\end{array}$} & STAFF & $\begin{array}{l}\text { - Job-intrinsic data file } \\
\text { - Job-extrinsic data file }\end{array}$ \\
\hline & FACULTY & $\begin{array}{l}\text { - Generic personal data file } \\
\text { - Job-intrinsic data file } \\
\text { - Job-extrinsic data file }\end{array}$ \\
\hline \multirow[t]{2}{*}{$\begin{array}{l}\text { CAREER } \\
\text { DEVELOPMENT }\end{array}$} & STAFF & $\begin{array}{l}\text { - Generic personal data file } \\
\text { - Exclusive personal data file } \\
\text { - Subjective data file }\end{array}$ \\
\hline & FACULTY & $\begin{array}{l}\text { - Generic personal data file } \\
\text { - Curriculum-vitae data file } \\
\text { - Subjective data file }\end{array}$ \\
\hline \multirow[t]{2}{*}{$\begin{array}{l}\text { PERFORMANCE } \\
\text { EVALUATION }\end{array}$} & STAFF & $\begin{array}{l}\text { - Generic personal data file } \\
\text { - Assessment data file }\end{array}$ \\
\hline & FACULTY & $\begin{array}{l}\text { - Generic personal data file } \\
\text { - Curriculum-vitae data file } \\
\text { - Student-survey data file }\end{array}$ \\
\hline \multirow[t]{2}{*}{$\begin{array}{l}\text { TRAINING AND } \\
\text { DEVELOPMENT }\end{array}$} & STAFF & $\begin{array}{l}\text { - Generic personal data file } \\
\text { - Exclusive personal data file }\end{array}$ \\
\hline & FACULTY & $\begin{array}{l}\text { - Generic personal data file } \\
\text { - Curriculum-vitae data file }\end{array}$ \\
\hline
\end{tabular}

* Data shared with other existing files in the university 


\section{ORGANIZATIONAL SOLUTION}

A moderately ambitious IS development project that attempts to go beyond a mere mechanization of working methods generally implies certain changes in the way in which organizations operate: new tasks are created, previous tasks are done differently, work interfaces are different, and so on. For these changes to be accepted by the organization, it is essential both to study the proposed technical solution and to introduce the necessary organizational improvements. The risks of failure of the whole project are thus minimized.

In this context, and according to the theoretical framework for university organizations -the professional organization- proposed by Mintzberg [11] it was judged appropriate to give a certain autonomy to the Human Resources Department, at least in those areas less affected by current legislation, and in such a way as to incorporate it into the technostructure (an element of the organization not directly related to the operating core and support staff), while the activities of recruitment, selection, salary administration, and social benefit planning were assigned to the already existing Personnel Service (within the support staff, as shown in Figure 1).

This part of the project concludes with the organization design of the new Human Resources Department and the creation of the function guide for each job.

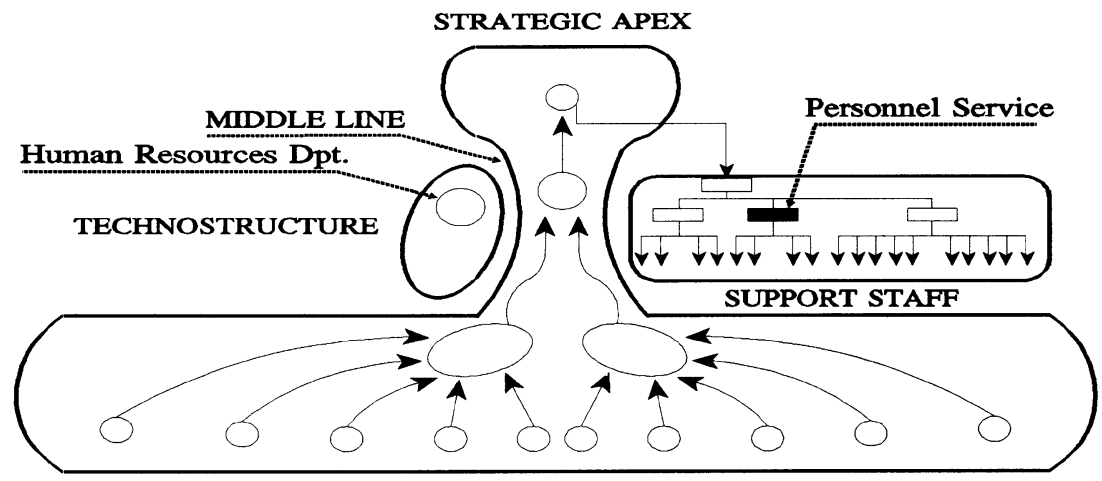

OPERATING CORE

Figure 1.

Human Resources Department's location in the university structure.

\section{CONCLUSIONS}

As the University is an organization whose main productive factor is the human one, it is essential to pay particular attention to and monitor the activities related with the new Human Resources Department. In this project, this area has been considered as a part of an 
interdependent whole in which IS/IT provide clear possibilities for management support and improvement.

Both the research team and the ULPGC's senior management hope that the new model for the Human Resources Department (now being introduced) with its information support systems will have a positive influence in the improvement of academic and research productivity in the university mainly in two ways:

1) Increased motivation of all university personnel (faculty and administrative staff), as a result of a considerable increase in the efficiency of job analysis and description, career development, and training and development, for which there will be adequate and valuable information available from now on.

2) Greater control of tasks and individual productivity by university management. This will stem from the broader possibilities for more effective performance evaluation provided by the new information system.

Besides these improvements at the operational level, we need to consider those which, at the strategic level, may accrue as a result of decision-making based on more reliable, accurate and up-to-date information.

It is important to highlight the low costs related to this development, as projects involving IS/IT are commonly associated with major capital investments. In this case, the hardware does not exceed $\$ 15,500$-mainly for new intelligent terminals connected to the mainframe- and $\$ 15,000$ in software -the cost of the development of the computer application for information management. This investment is relatively low if compared to the annual budget of over $\$ 103$ million required by the ULPGC, an organization with over 1,400 faculty, and 600 administrative staff educating over 22,000 students.

\section{REFERENCES}

1. M. Porter, Competitive Advantage: Creating and Sustaining Superior Performance, New York. The Free Press, 1985.

2. J. Ward, P. Griffiths and P. Whitmore, Strategic Planning for Information Systems, New York. John Wiley \& Sons, 1990.

3. J. Rockart, Harvard Business Review, March/April (1979)

4. G. Scott, Principles of Management Information Systems, New York. McGraw-Hill, 1986.

5. J. Senn, Analysis \& Design of Information Systems, New York. McGraw-Hill, 1989

6. J. Burch and G. Grudnitski, Information Systems Design, New York. John Wiley \& Sons, 1989.

7. W. Inmon and J. Caplan, Information Systems Architecture: Development in the 90's, Wellesley, MA. QED Information Sciences, 1992.

8. M. Peña Baztan, Dirección de Personal: Organización y Técnicas, Barcelona. Editorial Hispano Europea, 1986

9. D. DeCenzo and S. Robbins, Personnel/Human Resources Management, Englewoods Cliffs, NJ. Prentice Hall, 1988.

10. W. Werther and K. Davis, Personnel Management and Human Resources, New York. McGrawHill, 1987.

11. H. Mintzberg, Mintzberg on Management: Inside Our Strange World of Organizations, New York. The Free Press, 1989 